Delican, B. ve Gedik, O. (2020). Ortaokul öğrencilerinin dinleme/izleme stratejilerini kullanma durumları; ana dili açısından bir karşılaştırma. Ana Dili Eğitimi Dergisi, 8(3), 812-828.

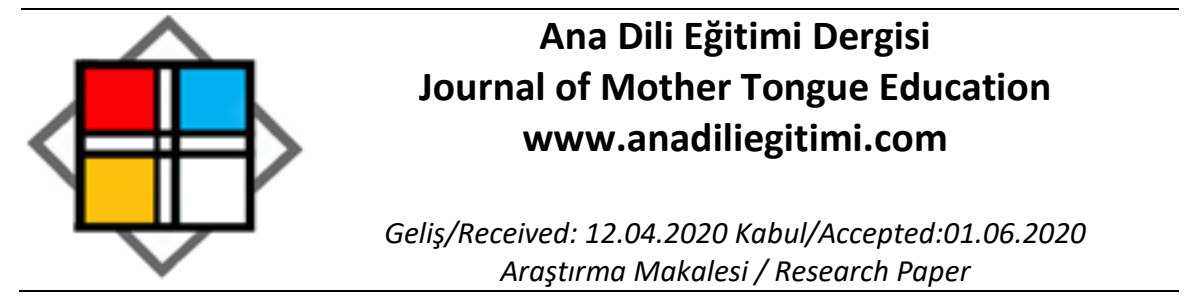

\title{
Ortaokul Öğrencilerinin Dinleme/İzleme Stratejilerini Kullanma Sıklıkları; Ana Dili Açısından Bir Karşılaştırma ***
}

\author{
Burak DELICAN $N^{* * *}$ \\ Osman GEDiK ${ }^{* * * *}$
}

\begin{abstract}
Öz
Bu araştırmanın temel amacı ana dili Türkçe olan ve olmayan ortaokul öğrencilerinin dinleme/izleme stratejilerini kullanma durumlarıı tarama modelinde betimsel bir bakış açısıyla ortaya koymaktır. Bu amaçla araştırmanın örnekleminde ana dili Türkçe olan ve olmayan 210 ortaokul öğrencisi yer almaktadır. Araştırma sürecinde veri toplama aracı olarak Doğan ve Erdem (2017) tarafından geliştirilen Ortaokul Öğrencilerinin Dinleme/İzleme Stratejileri Kullanım Sıklı̆̆ Ölçeği (DiSKSÖ) kullanılmıştır. Veri toplama süreci sonunda elde edilen veriler ölçeğin boyutları olan eleştirel dinleme/izleme, ayırt edici dinleme/izleme ve anlamlı dinleme/izleme boyutları açısından ve ölçeğin tamamı açısından değerlendirilmiştir. Dinleme/izleme stratejilerini kullanım sıklı̆ı ile cinsiyet arasında anlamlı bir ilişkinin olmadığı, dinleme/izleme stratejileri açısından ana dili Türkçe olan öğrencilerin ana dili Türkçe olmayan öğrencilere göre dinleme/izleme stratejilerini daha sık kullandıkları sonucuna ulaşıımıştır. DiSKSÖ'nün tamamı açısından ise 5. Sınıf öğrencilerinin 6,7 ve 8 . Sınıf öğrencilerinden; 6 ve 7. Sınıf öğrencilerinin de 8. Sınıf öğrencilerinden daha düşük sıklıkta dinleme/izleme stratejilerini kullandıkları ifade edilebilir.
\end{abstract}

Anahtar Kelimeler: ana dili, ortaokul öğrencileri, dinleme/izleme, dinleme/izleme stratejileri

\section{Secondary School Students' Usage of Listening / Viewing Strategies; A Comparison in terms of Mother Tongue}

\begin{abstract}
The main purpose of this research is to determine middle school students' using situation of listening/monitoring strategies whose mother tongue is Turkish or not. In this direction, it was aimed to reveal the frequency of using the listening / monitoring strategies of the middle school students whose mother tongue is Turkish or not, with a descriptive perspective in the survey model For this purpose, the sample of the research includes 210 secondary school students whose mother tongue is Turkish or not. In the research process, the Listening / Monitoring Strategies Usage Frequency Scale of the Secondary School Students (DiSKSÖ) developed by Doğan and Erdem (2017) were used as data collection instrument. The data obtained at the end of the data collection process were evaluated in terms of the dimensions of the scale, critical listening / monitoring, distinctive listening / monitoring, and meaningful listening / monitoring dimensions, and the entire scale. It was revealed that there was no significant relationship between frequency of using listening / monitoring strategies and gender. In terms of listening / watching strategies, it was revealed that students whose mother tongue is Turkish use listening /
\end{abstract}

\footnotetext{
* Bu araştırmanın bir kısmı V. Uluslararası TURKCESS Eğitim ve Sosyal Bilimler Kongresinde sözlü bildiri olarak sunulmuştur.

** Araştırmanın etik kurulu izni: Sivas ilı Milli Eğitim Müdürlüğü, 20.05.2019, 92255297-604.01.01-E.9915972.

*** Dr. Öğr. Üyesi, Tokat Gaziosmanpaşa Üniversitesi, Eğitim Fakültesi, Temel Eğitim Bölümü, Tokat, burakdelican@gmail.com, ORCID: orcid.org/ 0000-0003-3187-0001

**** Arş. Gör., Niğde Ömer Halisdemir Üniversitesi, Eğitim Fakültesi, Temel Eğitim Bölümü, Niğde, osmangedik@ohu.edu.tr, ORCID: orcid.org/0000-0002-6362-7607
} 
watching strategies more frequently than students whose mother tongue is not Turkish. In terms of the entire DiSKSÖ, it can be stated that 5th grade students use listening / watching strategies less frequently than 6th, 7th and 8th grade student and 6th and 7th grade students use listening / watching strategies less frequently than 8 th grade students.

Keywords: mother tongue, secondary school students, listening/viewing, listening strategies

\section{Giriş}

Dinleme becerisi anne karnından itibaren gelişimsel bir süreç olarak ilerlemektedir. Doğumdan itibaren dil becerilerinin gelişim alanları göz önüne alındığında dinleme becerisinin hem diğer gelişim alanları açısından hem de diğer dil becerileri olan konuşma, okuma ve yazma becerilerinin gelişiminde önemli bir konumda olduğu ifade edilebilir (Emiroğlu ve Pınar, 2013; Sadiku, 2015; Shanahan, MacArthur, Graham ve Fitzgerald, 2006; Temizyürek, 2007). Erken çocukluk döneminden itibaren ise alıcı dil becerisi olarak bireyin öğrenmelerinin büyük bir çoğunluğunu dinleme becerisi ile gerçekleşmektedir. Dinleme, konuşma dilinin anlama dönüştürüldüğü karmaşık fiziksel ve zihinsel etkinlikleri kapsayan, anlam oluşturmaya dayalı bir süreçtir (Akyol, 2016; Feyten, 1991; Purdy, 1997). Bu nedenle diğer dil becerilerinin gelişiminde de kritik bir etkiye sahiptir.

Moore (2001) dinlemenin dikkat, anlama ve değerlendirme olmak üzere üç aşamadan oluştuğunu ve bu aşamaların birlikte işe koşulduğu aktif bir süreci kapsadığını ifade etmektedir (Aktaran, Akyol 2016, s.3). Ayrıca ilgili literatürde araştırmacılar tarafından yapılan tanımlamalarda dinleme becerisi çeşitli aşamalarla ifade edilse de bu aşamaların işitme, dikkat, işitsel algı, dinleme ve dinlediğini anlama süreçlerini kapsadığı görülmektedir (Akyol, 2016; Güneş, 2007; Lundsteen, 1979; Moore, 2001; Özbay, 2009). Bu anlamda dinlemenin işitme ile başlayan ve anlam kurma ile sonuçlanan karmaşık bir zihinsel süreci ifade ettiği ve bu süreçte işe koşulan dinleme/izleme stratejilerinin anlam kurma sürecini en üst düzeye çıkarmada önemli bir etkisinin olduğu söylenebilir.

Insanlar doğumdan ölüme kadar geçen süreçte dinleme/izleme becerilerini değişik amaçlar için kullanmaktadırlar. Bu amaçlar dil, iletişim, sosyal ve zihinsel bağımsızlık becerilerini geliştirmek, bilgi toplamak, hoş vakit geçirmek, toplumsal iletişimi güçlendirmek, empati yeteneğini geliştirmek, eleştirel düşünmek, duygu dünyasını genişletmek, başka insanların tecrübelerinden faydalanmak ve saygı göstermek olarak ifade edilebilir (Akyol, 2016; Güneş, 2007; Mackay, 1997; Özbay, 2007). Bu süreçte bireyler çeşitli dinleme/izleme türlerini işe koşmaktadırlar. Örneğin ayırt edici dinleme ile görsel ve işitsel uyarıcılar, bir içeriği değerlendirmek için eleştirel dinleme, işitilen ve izlenen bir içeriği anlamlandırmak için anlamlı dinleme türleri kullanılmaktadır. Günlük hayatın her aşamasında kullanılan dinleme, ayırt edici, kapsamlı, terapatik, eleştirel, estetik ve anlamlı dinleme olarak sınıflandırılabilmektedir (Wolvin ve Coakley, 1996).

Illkokula başlamakla birlikte dinleme becerisinin kritik etkisinin daha da belirginleştiği görülmektedir. Özellikle bireyin öğrenmelerinin büyük bir çoğunluğunun dinleme ile gerçekleştiği göz önüne alındığında bireyin akademik gelişimi açısından dinleme becerisinin önemli bir faktör olduğu söylenebilir. İlkokul ve ortaokul öğrencilerinin dinleme becerileri üzerine yapılan araştırmaların sonuçları bu durumu destekler niteliktedir (Durmuş, 2013; Fisher ve McDonald, 2001; Şahin, 2015).

Erken çocukluk döneminden itibaren dinleme becerisinde ortaya çıkabilecek olumsuzlukların diğer dil becerileri olan konuşma, okuma ve yazma becerilerini de olumsuz etkileyebileceği ifade edilebilir (Bozorgian, 2012; Yalçınkaya, Muluk ve Şahin, 2009). Özellikle işitsel ayrım, dikkat ve dinlediğini anlamada sorun yaşayan öğrencilerin ilk okuma yazma sürecinde sesleri ayırt etme, birleştirme ve anlamlandırmada güçlük çektikleri pek çok araştırmanın sonuçlarında yer almaktadır (Palincsar, 1991; Snow, Tabors, Nicholson ve Kurland, 1995). Araştırmacılar sistematik olarak uygulanan dinleme becerisini geliştirme programlarının bireyin dinleme becerilerini olumlu yönde etkilediğini vurgulamaktadır (Casbergue ve Harris, 1996; Hampleman, 1958). Bu anlamda dinlemenin bir yaşam boyu öğrenme becerisi olarak okuryazarlık becerilerinin gelişiminde de önemli bir etkisi bulunmaktadır.

Türk eğitim sistemine bakıldığında siyasal, toplumsal, kültürel olaylar ve coğrafi konum nedeniyle ana dili Türkçe olmayan pek çok öğrencinin eğitim sistemi içinde bulunduğu ifade edilebilir. Türk eğitim sistemi içerisinde bu öğrencilerin ana dillerinden farklı olarak ikinci dilleri olan Türkçe ile 
öğrenme etkinlikleri içinde bulundukları görülmektedir. Bu süreç içerisinde ana dili Türkçe olmayan öğrencilerin öğrenme etkinliklerinde çeşitli sorunlar yaşadığı çoğu çalışmanın sonuçları arasında yer almaktadır (Kan ve Yeşiloğlu, 2017; Yıldız ve Kızıltaş, 2018). Bununla birlikte erken çocukluk döneminden itibaren ikinci dilin geliştirilmesi üzerine uygulanan programlar yaşanan güçlüklerin giderilmesinde etkili olabilmektedir.

Illkokulun ilk yıllarından itibaren eğitimciler, ana dili Türkçe olmayan öğrencilerin dinleme/izleme becerilerini desteklemek için pek çok çalışma yürütmektedirler. Bununla birlikte ana dili Türkçe olmayan öğrencilerin ortaokula gelene dek dinleme/izleme becerilerinde önemli bir ilerleme gözlenebileceği gibi bu ilerlemeyi gerçekleştiremeyen öğrencilerin de olabilmesi mümkündür. Öğrencilerin ortaokula başlamakla birlikte kendisinden beklenen akademik etkinliklerin arttığı da göz önüne alındığında, ana dili Türkçe olmayan öğrencilerin dinleme becerilerinde yaşayabilecekleri sorunların diğer öğrenme süreçlerini de olumsuz etkileyebileceği ifade edilebilir. Durum bu açıdan değerlendirildiğinde ortaokul öğrencilerinin özellikle de ana dili Türkçe olmayan ortaokul öğrencilerinin dinleme/izleme stratejilerini kullanma sıklıkları bireyin öğrenme süreçlerine, gündelik yaşamına ve akademik başarııına etki edebilmektedir.

Bu noktadan hareketle yapılan araştırmanın temel amacı ana dili Türkçe olan ve olmayan ortaokul öğrencilerinin dinleme/izleme stratejilerini kullanma sıklıklarının belirlenmesidir. Bu temel amaç doğrultusunda aşağıdaki sorulara cevap aranmıştır:

1. Ortaokul öğrencilerinin dinleme/izleme stratejilerini kullanma sıklıkları ne düzeydedir?

2. Ana dili Türkçe olan ve olmayan ortaokul öğrencilerinin dinleme/izleme stratejilerini kullanma sıklıkları anlamlı olarak farklılaşmakta mıdır?

3. Ana dili Türkçe olan ve olmayan ortaokul öğrencilerinin dinleme/izleme stratejilerini kullanma sıklıkları cinsiyet açısından anlamlı olarak farklılaşmakta mıdır?

4. Ana dili Türkçe olan ve olmayan ortaokul öğrencilerinin dinleme/izleme stratejilerini kullanma sıklıkları sınıf düzeyi açısından anlamlı olarak farklılaşmakta mıdır?

\section{Araştırmanın Modeli}

\section{Yöntem}

$\mathrm{Bu}$ çalışma nicel araştırmanın yapısına uygun olarak betimsel tarama modelinde gerçekleştirilmiştir. Betimsel tarama modelinde örneklem üzerinde herhangi bir değişiklik yapılmadan nicel veriler doğrultusunda evrendeki genel eğilim, tutum ve görüşler betimlenmeye çalışılmaktadır (Creswell, 2013). Bu sebeple yapılan çalışmada araştırmanın amacına uygun olarak, nicel araştırma yöntemlerinden biri olan betimsel tarama modeli kullanılmıştır. Bu doğrultuda ana dili Türkçe olan ve olmayan ortaokul öğrencilerinin dinleme/izleme becerilerinin kullanım sıklıkları sınıf düzeyi ve cinsiyet açısından karşılıklı incelenerek betimsel bir bakış açısıyla sunulmuştur.

\section{Örneklem}

Araştırmanın çalışma evreninde 2018-2019 eğitim-öğretim yılı bahar döneminde Sivas ilinde öğrenim gören ana dili Türkçe olan ve olmayan ortaokul öğrencileri bulunmaktadır. Araştırmada çalışma evrenini temsil edebilmek için uygun örnekleme yöntemi kullanılmıştır. Uygun örnekleme, araştırmada ihtiyaç duyulan büyüklüğe ve özelliklere ulaşmada en yüksek tasarrufu sağlamada sıklıkla kullanılan bir yöntemdir (Büyüköztürk, Kılıç Çakmak, Akgün, Karadeniz ve Demirel, 2018). Bu araştırmada ana dili Türkçe olmayan ortaokul öğrencilerine de ulaşılmak istenildiğinden uygun örnekleme yöntemi tercih edilmiştir. Bu doğrultuda araştırmanın örnekleminde 210 ortaokul öğrencisi yer almaktadır. Örneklemde yer alan ortaokul öğrencilerinin ana dili, cinsiyet ve sınıf düzeyi değişkenleri açısından dağılımı Tablo 1'de ifade edilmiştir. 
Tablo 1.

Ortaokul Öğrencilerinin Ana Dili, Cinsiyet ve Sınıf Düzeyi Değişkenleri Açısından Dağılımı

\begin{tabular}{cccccccc}
\hline \multirow{2}{*}{ Sınıf Düzeyi } & \multicolumn{3}{c}{ Ana Dili Türkçe Olan } & \multicolumn{5}{c}{ Ana Dili Türkçe Olmayan } \\
\cline { 2 - 8 } & Kız & Erkek & Toplam & Kız & Erkek & Toplam & Toplam \\
\hline 5 & 9 & 20 & 29 & 13 & 15 & 28 & 57 \\
6 & 15 & 8 & 23 & 17 & 5 & 22 & 45 \\
7 & 11 & 11 & 22 & 11 & 12 & 23 & 45 \\
8 & 18 & 12 & 30 & 18 & 15 & 33 & 63 \\
\hline Toplam & 53 & 51 & 104 & 59 & 47 & 106 & 210 \\
\hline
\end{tabular}

Tablo $1^{\prime}$ de ifade edildiği üzere örneklemde yer alan ortaokul öğrencilerinin 106 'sı ana dili Türkçe olmayan, 104'ü ana dili Türkçe olan öğrencilerdir. Örneklemde yer alan öğrencilerin 113'ü erkek, 98'i kızdır. Sınıf düzeyi açısından ise 57 beşinci sınıf, 45 altıncı sınıf, 45 yedinci sınıf ve 63 sekizinci sınıf öğrencisi yer almaktadır.

\section{Veri Toplama Araçları}

Araştırma sürecinde veriler Kişisel Bilgi Formu ve Doğan ve Erdem (2017) tarafından geliştirilen Ortaokul Öğrencilerinin Dinleme/İzleme Stratejilerini Kullanım Sıklığı Ölçeği (DiSKSÖ) ile toplanmıştır. Kişisel Bilgi Formu öğrencilerin cinsiyet ve sınıf seviyeleri ile ilgili iki soru içermekte olup bağımsız değişkenleri kapsamaktadır. DiSKSÖ'de ise dinleme/izleme stratejileri; eleştirel, anlamlı ve ayırt edici dinleme boyutları altında 19 madde ile tanımlanmıştır. Ölçek, dinleme/izleme stratejilerinin kullanım sıklığını belirtmek üzere 1 hiçbir zaman, 5 her zaman olmak üzere beşli Likert tipinde oluşturulmuştur.

\section{Verilerin Toplanması}

Çalışmada veriler 2018-2019 eğitim-öğretim yılı bahar döneminde Sivas ilinde bulunan ortaokullardan elde edilmiştir. Veri toplama sürecinde ölçek formları Millî Eğitim Bakanlığına bağlı ortaokullarda eğitim-öğretim gören ortaokul öğrencilerine uygulanmıştır. Millî Eğitim Müdürlüğünden alınan izinler doğrultusunda belirlenen ortaokulların yöneticileri ile görüşülmüş okullarında bulunan ana dili Türkçe olmayan öğrenci sayıları hakkında bilgi alınmıştır. Bu doğrultuda Sivas il merkezinde bulunan üç okuldan veri toplamanın uygun olacağına karar verilmiştir. Okullar belirlendikten sonra ders öğretmenleri ile araştırmanın amacı paylaşılmış ve ana dili Türkçe olan ve olmayan ortaokul öğrencilerinin formları doldurması sağlanmıştır. Gönüllü olmayan ve veri toplama araçlarını cevaplamayan veya birden fazla aynı cevabı veren öğrenciler çalışmaya dâhil edilmemiştir. Veri toplama süreci sonucunda 210 ortaokul öğrencisinden elde edilen verinin değerlendirilebilir olduğu görülmüştür.

\section{Verilerin Analizi}

Dinleme/İzleme Stratejilerini Kullanım Sıklığı Ölçeğinden elde edilen veriler SPSS 18 analiz programı aracılığıyla analiz edilmiş̧ir. SPSS 18 programına aktarılan veriler, analize başlanmadan önce uç, sapan, eksik ve hatalı değerlerden arındırımıştır. Yapılan düzenleme sonucunda 210 öğrenciden gelen yanıtlar doğrultusunda analizler yapılmıştır. illk olarak veri setinin normallik varsayımını karşılayıp karşılamadığı incelenmiştir. Dinleme/i̇zleme Stratejilerini Kullanım Sıklığı Ölçeğinden elde edilen verilerin normallik varsayımını karşılayıp karşılamadığı Kolmogorov - Smirnov testi ile incelenmiştir. Ulaşılan p değerlerinin 0,05 altında olduğu görülmüştür. Bu bulgu, Dinleme/ İzleme Stratejilerini Kullanım Sıklığ Ölçeğinden elde edilen puanların normal dağılım göstermediği şeklinde yorumlanabilir. Çokluk, Şekercioğlu ve Büyüköztürk (2012) örneklem büyüklüğü arttıkça küçük farkların anlamlı çıkma olasılığının artma eğiliminde olduğunu belirtmektedir. Dinleme/ İzleme Stratejilerini Kullanım Sıklığı Ölçeği ile 210 öğrenciden veri toplandığı göz önüne alınarak puanların 
normallik durumu basıklık, çarpıklık katsayıları, histogram, gövde-yaprak diyagramı, Q-Q grafiği ve kutu çizgi grafiği ile tekrar incelenmiştir.

Dinleme/Izzleme Stratejilerini Kullanım Sıklığı Ölçeğinden elde edilen verilere yönelik ortaya çıkan ortalama $(61,01)$, medyan $(62,00)$ ve mod $(60,00)$ değerlerinin birbirlerine yakın olduğu görülmektedir. Çarpıklık ve basıklık katsayısı ise sırasıyla $-0,372 ;-0,334^{\prime}$ tür. Ortaya çıkan çarpıklık ve basıklık katsayısı -1 ile +1 aralığında yer almaktadır. Bu durum histogram, Q-Q ve kutu çizgi grafiği ile birlikte değerlendirildiğinde Dinleme/i̇zleme Stratejilerini Kullanım Sıklığı Ölçeğinden elde edilen puanların normal dağılımından fazla uzaklaşmadığı şeklinde yorumlanabilir. Bu nedenle ana dili ve cinsiyet açısından yapılan analizlerde bağımsız örneklem t-Testi uygulanmış; sınıf düzeyi açısından yapılan analizde ise tek yönlü varyans analizi gerçekleştirilmiştir.

\section{Geçerlik ve Güvenirlik}

Dinleme/İzleme Stratejilerini Kullanma Sıklığı Ölçeğinin geçerlik analizleri sonucunda ölçeğin üç faktör altında toplam varyansın \%47,9'unu açıkladığı görülmüştür. Doğrulayıcı faktör analizi sonucunda oluşturulan yapının uyum indekslerinin kabul edilebilir sınırlar içinde olduğu belirlenmiştir. Aracın Cronbach Alpha iç tutarlıık katsayısı 0.89 olarak hesaplanmıştır. Bulgular sonucunda ölçeğin dinleme/izleme stratejilerinin kullanım sıklığını geçerli ve güvenilir bir şekilde ölç̧üğü ifade edilmektedir (Doğan ve Erdem, 2017). Veri toplama sürecinde güvenirliği sağlamak için önce öğretmenler ve öğrenciler konu hakkında bilgilendirilmiştir. Öğrencilerin Dinleme/izleme Stratejilerini Kullanım Sıklığı Ölçeğini (Doğan ve Erdem, 2017) nasıl doldurmaları gerektiği hakkında bilgilendirme yapılmıştır. Bununla birlikte öğrencilerden elde edilen verilerin gerçekliğini sağlamak için gönüllü olarak araştırmaya katılmak isteyen öğrencilerin verileri değerlendirmeye alınmıştır.

\section{Etik Kurulu İzni}

Araştırma bulguları V. Uluslararası TURKCESS Eğitim ve Sosyal Bilimler Kongresinde sözlü bildiri olarak sunulmuş olup bildiri özet kitapçığında yayımlanmıştır. Araştırma 2020 yılından önce gerçekleştiği için etik kurul izni bulunmamaktadır. Bununla birlikte Millî Eğitim Müdürlüğünden alınan araştırma izninin bilgileri aşağıda belirtilmiştir.

İzin Alınan Kurum: Sivas ill Millî Eğitim Müdürlüğü

Sayı ve Tarih:92255297-604.01.01-E.9915972 / 20.05.2019

Konu: Araştırma İni (Burak DELICAN)

\section{Bulgular}

Bu kısımda araştırmanın veri analizi sürecinde ulaşılan bulgular tablolar aracılığıyla ifade edilmiştir. İlk olarak ana dili Türkçe olan ve olmayan öğrencilerin DiSKS ölçeğinin boyutlarından ve tamamından aldıkları puanların t-Testi sonuçları sunulmuş devamında ölçeğin boyutları olan eleştirel, anlamlı ve ayırt edici dinleme boyutları açısından bulgular ifade edilmiştir. Son olarak ana dili, cinsiyet ve sınıf düzeyi değişkenleri açısından ulaşılan bulgular sunulmuştur.

Ana dili Türkçe olan ve olmayan ortaokul öğrencilerinin DiSKS ölçeğinin boyutlarından ve tamamından aldıkları puanların t-Testi sonuçları Tablo 2'de sunulmuştur.

Tablo 2.

Ortaokul Öğrencilerinin DiSKS Ölçeğinden Aldıkları Ortalama Puanların Ana Dili Değişkeni Açısından tTesti Sonuçları

\begin{tabular}{llllllll}
\hline Boyut & Ana Dili & $\mathrm{n}$ & $\bar{X}$ & $\mathrm{~s}$ & $\mathrm{sd}$ & $\mathrm{t}$ & $\mathrm{p}$ \\
\hline \multirow{2}{*}{ Eleştirel Dinleme/i̇zleme } & Türkçe & 104 & 3,49 & 0,96 & 208 & 2,84 & 0.001 \\
& Türkçe Değil & 106 & 2,94 & 0,83 & & & \\
\multirow{2}{*}{ Anlamlı Dinleme/Izleme } & Türkçe & 104 & 3,39 & 0,89 & 208 & 2,26 & 0.005 \\
Ayırt Edici Dinleme/izleme & Türkçe Değil & 106 & 2,89 & 0,72 & & & \\
& Türkçe & 104 & 3,56 & 0,92 & 208 & 4,26 & 0.024
\end{tabular}




\begin{tabular}{llllllll} 
& Türkçe Değil & 106 & 3,02 & 0,87 & & & \\
\hline \multirow{2}{*}{ Toplam } & Türkçe & 104 & 3,47 & 0,83 & 208 & 3,48 & 0.000 \\
& Türkçe Değil & 106 & 2,95 & 0,87 & & & \\
\hline
\end{tabular}

Tablo 2'de ifade edilen veriler incelendiğinde, örneklemde yer alan ortaokul öğrencilerinin DiSKS ölçeğinden aldıkları ortalama puanlar arasında ana dili açısından anlamlı bir farklılık olduğu görülmektedir $\mathrm{t}(208)=3.48,(p<0.01)$. Ölçeğin alt boyutları olan eleştirel dinleme/izleme, anlamlı dinleme/izleme ve ayırt edici dinleme/izleme boyutları açısından ana dili Türkçe olan öğrencilerin lehine ortalama puanların anlamlı olarak farklılaştığı ifade edilebilir. Bu bulgu doğrultusunda dinleme/izleme stratejileri açısından ana dili Türkçe olan öğrencilerin $(=3,47)$ ana dili Türkçe olmayan öğrencilere $(=2,95)$ göre dinleme/izleme stratejilerini daha sık kullandıkları söylenebilir.

Ana dili Türkçe olan ve olmayan ortaokul öğrencilerinin DiSKS ölçeğinin eleştirel dinleme/izleme stratejileri boyutunda yer alan maddelere ilişkin ortalama ve standart sapma değerleri Tablo 3'te sunulmuştur.

Tablo 3.

Ortaokul Öğrencilerinin DiSKS Ölçeğinin Eleştirel Dinleme/Izleme Stratejileri Boyutunda Yer Alan Maddelere ilişskin Ortalama ve Standart Sapma Değerleri

\begin{tabular}{|c|c|c|c|c|c|}
\hline \multirow{3}{*}{ No } & \multirow{3}{*}{ Eleştirel Dinleme/İzleme Stratejileri ile İlgili Maddeler } & \multicolumn{4}{|c|}{ Ana Dili Türkçe } \\
\hline & & \multicolumn{2}{|c|}{$\begin{array}{c}\text { Olan } \\
(n=104)\end{array}$} & \multicolumn{2}{|c|}{$\begin{array}{l}\text { Olmayan } \\
(n=106)\end{array}$} \\
\hline & & $\bar{X}$ & SS & $\bar{X}$ & SS \\
\hline 1 & $\begin{array}{l}\text { Dinlediğim/izlediğim metindeki örneklerin/karakterlerin inandırıcı } \\
\text { olup olmadığını sorgularım. } \\
\text { Dinlediğim/izlediğim metinde dinleyicileri etkilemek amacıyla }\end{array}$ & 3.01 & 1.13 & 2.8 & 1.23 \\
\hline 2 & $\begin{array}{l}\text { konunun belirli bir yönünün özellikle mi vurgulandığını } \\
\text { sorgularım. }\end{array}$ & 3.92 & 1.13 & 2.87 & 1.30 \\
\hline 3 & $\begin{array}{l}\text { Dinlediğim/izlediğim metnin vermeyi amaçladığı mesajın amacına } \\
\text { uygun olup olmadığını sorgularım. }\end{array}$ & 3.25 & 1.12 & 2.99 & 1.33 \\
\hline 4 & $\begin{array}{l}\text { Dinlediğim/izlediğim metinde verilmek istenen mesajda gerçeği } \\
\text { yansıtmayan cümlelerde aldatıcı bir dil kullanıldı̆ında bunu fark } \\
\text { ederim. }\end{array}$ & 3.31 & 1.26 & 2.76 & 1.37 \\
\hline 5 & $\begin{array}{l}\text { Dinlediğim/izlediğim metinde konu ile ilgili düşüncelerimi } \\
\text { değiştirmek üzere aldatıcı bir dil kullanılırsa bunu fark ederim. }\end{array}$ & 3.52 & 1.23 & 3.16 & 1.32 \\
\hline 6 & $\begin{array}{l}\text { Sınıf içinde öğretmenimi, arkadaşlarımı dinlerken belirli bir kişi } \\
\text { haksız yere küçük düşürülmeye çalışııırsa bunu fark ederim. }\end{array}$ & 3.95 & 1.28 & 3.11 & 1.31 \\
\hline
\end{tabular}

Tablo 3'te ifade edildiği üzere ana dili Türkçe olan öğrencilerin ana dili Türkçe olmayan öğrencilere göre eleştirel dinleme/izleme stratejilerini daha fazla kullandıkları ifade edilebilir. Ana dili Türkçe olan öğrencilerin ölçek puanlarının ortalamalarının ana dili Türkçe olmayan öğrencilerin ölçek puanlarının ortalamalarından daha yüksek olduğu görülmektedir. Ana dili Türkçe olan öğrencilerin eleştirel dinleme/izleme stratejilerini kullanma sıkıkları ara sıra - genellikle olarak ifade edilebilirken ana dili Türkçe olmayan öğrencilerin dinleme/izleme stratejilerini kullanma sıklıkları nadiren-ara sıra olarak tanımlanabilir. Bu durum ana dili Türkçe olmayan öğrencilerin eleştirel dinleme/izleme stratejilerini ana dili Türkçe olan öğrencilere göre daha az kullandıkları şeklinde yorumlanabilir.

Ana dili Türkçe olan ve olmayan ortaokul öğrencilerinin DiSKS ölçeğinin anlamlı dinleme/izleme stratejileri boyutunda yer alan maddelere ilişkin ortalama ve standart sapma değerleri Tablo 4'te sunulmuştur. 
Ortaokul Öğrencilerinin Dinleme/İzleme Stratejilerini Kullanma Durumları; Ana Dili Açısından Bir Karşılaştırma

Tablo 4.

Ortaokul Öğrencilerinin DiSKS Ölçeğinin Anlamlı Dinleme/izleme Stratejileri Boyutunda Yer Alan Maddelere Iliş̧kin Ortalama ve Standart Sapma Değerleri

\begin{tabular}{|c|c|c|c|c|c|}
\hline \multirow{3}{*}{ No } & \multirow{3}{*}{ Anlamlı Dinleme/ízleme Stratejileri ile İlgili Maddeler } & \multicolumn{4}{|c|}{ Ana Dili Türkçe } \\
\hline & & \multicolumn{2}{|c|}{$\begin{array}{c}\text { Olan } \\
(n=104)\end{array}$} & \multicolumn{2}{|c|}{$\begin{array}{c}\text { Olmayan } \\
(\mathrm{n}=106)\end{array}$} \\
\hline & & $\bar{X}$ & SS & $\bar{X}$ & SS \\
\hline 7 & $\begin{array}{l}\text { Dinlediğim/izlediğim metinde özellikle vurgulanan noktaları not } \\
\text { ederim. }\end{array}$ & 3.12 & 1.19 & 3.03 & 1.24 \\
\hline 8 & $\begin{array}{l}\text { Dinlediğim/izlediğim metinde ana fikri bulduracak anahtar } \\
\text { kelimeleri tespit etmeye çalışırım. }\end{array}$ & 3.82 & 1.04 & 2.15 & 1.28 \\
\hline 9 & $\begin{array}{l}\text { Dinlediğim/izlediğim metinde ana fikri bulduracak yardımcı } \\
\text { düşünceleri not alırım. }\end{array}$ & 3.18 & 1.12 & 2.81 & 1.32 \\
\hline 10 & $\begin{array}{l}\text { Dinlediğim/izlediğim metinde konuşmacının vermek istediği ana } \\
\text { fikri bulmaya çalışırım. }\end{array}$ & 3.38 & 1.07 & 3.19 & 1.32 \\
\hline 11 & $\begin{array}{l}\text { Dinlemeye/izlemeye başlamadan önce niçin } \\
\text { dinleyeceğime/izleyeceğime yönelik bir amaç belirlerim. } \\
\text { Dinlediğim/izlediğim metindeki sebep-sonuç, amaç-sonuç, }\end{array}$ & 3.4 & 1.17 & 3.0 & 1.24 \\
\hline 12 & $\begin{array}{l}\text { karşılaştırma vb. anlamlar bildiren bağlantı ögelerini belirlemeye } \\
\text { çalışırım. }\end{array}$ & 3.43 & 1.24 & 3.03 & 1.21 \\
\hline 13 & $\begin{array}{l}\text { Dinlediğim/izlediğim metindeki sebep-sonuç, amaç-sonuç, } \\
\text { karşılaştırma vb. anlamlar bildiren bağlantı ögelerinin metne } \\
\text { kattıkları anlamları çözmeye çalışırım. }\end{array}$ & 3.4 & 1.18 & 3.04 & 1.26 \\
\hline 14 & $\begin{array}{l}\text { Dinlediğim/izlediğim metinde geçenleri hatırlamak için kodlama, } \\
\text { olay oluş sırasını not alma, sınıflama gibi hafıza tekniklerini } \\
\text { kullanırım. }\end{array}$ & 3.16 & 1.09 & 3.06 & 1.34 \\
\hline
\end{tabular}

Tablo 4'te ana dili Türkçe olan öğrencilerin ana dili Türkçe olmayan öğrencilere göre anlamlı dinleme/izleme stratejilerini daha fazla kullandıkları görülmektedir. Ana dili Türkçe olan öğrencilerin ortalamalarının ana dili Türkçe olmayan öğrencilerin ortalamalarından daha yüksek olduğu söylenebilir. Ana dili Türkçe olan öğrencilerin anlamlı dinleme/izleme stratejileri kullanma sıklıkları ara sıra - genellikle olarak ifade edilebilirken ana dili Türkçe olmayan öğrencilerin dinleme/izleme stratejilerini kullanma sıklıkları nadiren-ara sıra olarak tanımlanabilir. Bu durum ana dili Türkçe olmayan öğrencilerin anlamlı dinleme/izleme stratejilerini ana dili Türkçe olan öğrencilere göre daha az kullandıkları şeklinde yorumlanabilir.

Ana dili Türkçe olan ve olmayan ortaokul öğrencilerinin DiSKS ölçeğinin ayırt edici dinleme/izleme stratejileri boyutunda yer alan maddelere ilişkin ortalama ve standart sapma değerleri Tablo 5'te sunulmuştur.

Tablo 5.

Ortaokul Öğrencilerinin DiSKS Ölçeğinin Ayırt Edici Dinleme/Izleme Stratejileri Boyutunda Yer Alan Maddelere Iliş̧kin Ortalama ve Standart Sapma Değerleri

\begin{tabular}{|c|c|c|c|c|c|}
\hline \multirow{3}{*}{ No } & \multirow{3}{*}{ Ayırt Edici Dinleme/İzleme Stratejileri ile Illgili Maddeler } & \multicolumn{4}{|c|}{ Ana Dili Türkçe } \\
\hline & & \multicolumn{2}{|c|}{$\begin{array}{c}\text { Olan } \\
(n=104)\end{array}$} & \multicolumn{2}{|c|}{$\begin{array}{c}\text { Olmayan } \\
(n=106)\end{array}$} \\
\hline & & $\overline{\bar{X}}$ & SS & $\overline{\bar{X}}$ & SS \\
\hline 15 & $\begin{array}{l}\text { Bir metni dinlerken/izlerken konuşmacının ses tonu değişimine, } \\
\text { jest ve mimiklerine bakarak ondaki duygu değişimlerini ayırt }\end{array}$ & 3.57 & 1.24 & 3.03 & 1.40 \\
\hline
\end{tabular}


etmeye çalışırım.

Dinlediğim/izlediğim bir konuşmacının bana beden diliyle sözel

olmayan bir mesajı vermeye çalışıp çalışmadığına dikkat ederim.

$\begin{array}{llll}3.53 & 1.26 & 2.15 & 1.28\end{array}$

Dinlediğim/izlediğim kişinin konuşma anındaki ses tonunda

17 değişiklik olup olmadığına (sesi yükseltip alçaltma, vurgulama)

$\begin{array}{llll}3.52 & 1.19 & 2.81 & 1.38\end{array}$

dikkat ederim.

18

Aynı kelimelerin farklı vurgu ve tonlamalarla sesli okunduğunda

hangi duyguları çağrıştırdığını tahmin edebilirim.

$\begin{array}{llll}3.81 & 1.19 & 3.19 & 1.31\end{array}$

İzlediğim kişinin konuşma anındaki jest ve mimiklerini nasıl

19 kullandığını gözlemlerim.

$\begin{array}{llll}3.80 & 1.37 & 3.00 & 1.33\end{array}$

Tablo 5'te ana dili Türkçe olan öğrencilerin ana dili Türkçe olmayan öğrencilere göre ayırt edici dinleme/izleme stratejilerini daha fazla kullandıkları görülmektedir. Ana dili Türkçe olan öğrencilerin ortalamalarının ana dili Türkçe olmayan öğrencilerin ortalamalarından daha yüksek olduğu söylenebilir. Ana dili Türkçe olan öğrencilerin ayırt edici dinleme/izleme stratejilerini kullanma sıklıkları ara sıra - genellikle olarak ifade edilebilirken ana dili Türkçe olmayan öğrencilerin ayırt edici dinleme/izleme stratejilerini kullanma sıklıkları nadiren-ara sıra olarak tanımlanabilir. Bu durum ana dili Türkçe olmayan öğrencilerin ayırt edici dinleme/izleme stratejilerini ana dili Türkçe olan öğrencilere göre daha az kullandıkları şeklinde yorumlanabilir.

DiSKS Ölçeğinden elde edilen toplam puanların cinsiyet açısından t-Testi sonuçları Tablo 6'da sunulmuştur.

Tablo 6.

DiSKS Ölçeğinden Elde Edilen Toplam Puanların Cinsiyet Değişkeni Açısından t-Testi Sonuçları

\begin{tabular}{llcccccc}
\hline Boyut & Cinsiyet & $\mathrm{n}$ & $\bar{X}$ & $\mathrm{~S}$ & $\mathrm{sd}$ & $\mathrm{t}$ & $\mathrm{p}$ \\
\hline Eleştirel & Kız & 112 & 20.12 & 4.96 & 208 & 3.19 & 0.102 \\
Dinleme/izleme & Erkek & 98 & 17.73 & 5.86 & & & \\
Anlamlı & Kız & 112 & 25.82 & 6.53 & 208 & 1.53 & 0.126 \\
Dinleme/izleme & Erkek & 98 & 24.42 & 6.59 & & & \\
Ayırt Edici & Kız & 112 & 17.33 & 4.86 & 208 & 1.55 & 0.122 \\
Dinleme/izleme & Erkek & 98 & 16.24 & 5.25 & & & \\
\hline \multirow{2}{*}{ Toplam } & Kız & 112 & 63.27 & 14.05 & 208 & 2.36 & 0.190 \\
& Erkek & 98 & 58.40 & 15.02 & & & \\
\hline
\end{tabular}

Tablo 6'da ortaokul öğrencilerinin DiSKSÖ puanlarında cinsiyet değişkeni açısından anlamlı bir farklııık olmadığı görülmektedir $t(208)=0.19,(p>0,01)$. Ölçeğin alt boyutları olan eleştirel, anlamlı ve ayırt edici dinleme izleme stratejileri açısından da ortaokul öğrencilerinin ölçekten aldıkları toplam puanların cinsiyet açısından anlamlı olarak farklılaşmadığı söylenebilir. Bu bulgu dinleme/izleme stratejilerini kullanım sıklığı ile cinsiyet arasında anlamlı bir ilişkinin olmadığı şeklinde yorumlanabilir.

Ana dili Türkçe olan ortaokul öğrencilerinin DiSKS ölçeğinden aldıkları puanların cinsiyet açısından t-Testi puanları Tablo 7'de sunulmuştur.

Tablo 7.

Ana Dili Türkçe Olan Ortaokul Öğrencilerinin DiSKS Ölçeğinden Aldıkları Puanların Cinsiyet Açısından tTesti Puanları

\begin{tabular}{llllllllll}
\hline Ana Dili & Boyut & Cinsiyet & $\mathrm{n}$ & $\bar{X}$ & $\mathrm{~s}$ & $\mathrm{sd}$ & $\mathrm{t}$ & $\mathrm{p}$ \\
\hline
\end{tabular}


Ortaokul Öğrencilerinin Dinleme/İzleme Stratejilerini Kullanma Durumları; Ana Dili Açısından Bir Karşılaştırma

\begin{tabular}{|c|c|c|c|c|c|c|c|c|}
\hline \multirow{8}{*}{$\begin{array}{l}\text { Türkçe } \\
\text { Olan }\end{array}$} & \multirow{2}{*}{$\begin{array}{l}\text { Eleştirel } \\
\text { Dinleme/Izzleme }\end{array}$} & $\mathrm{K} ı \mathrm{Z}$ & 53 & 24.41 & 5.59 & \multirow[t]{2}{*}{102} & \multirow[t]{2}{*}{1.98} & \multirow[t]{2}{*}{0.049} \\
\hline & & Erkek & 51 & 21.96 & 6.96 & & & \\
\hline & \multirow{2}{*}{$\begin{array}{l}\text { Anlamlı } \\
\text { Dinleme/İzleme }\end{array}$} & $\mathrm{K} ı \mathrm{Z}$ & 53 & 26.52 & 7.46 & \multirow[t]{2}{*}{102} & \multirow[t]{2}{*}{0.47} & \multirow[t]{2}{*}{0.639} \\
\hline & & Erkek & 51 & 25.86 & 6.95 & & & \\
\hline & \multirow{2}{*}{$\begin{array}{l}\text { Ayırt Edici } \\
\text { Dinleme/İzleme }\end{array}$} & $\mathrm{K} ı \mathrm{z}$ & 53 & 18.96 & 4.84 & \multirow[t]{2}{*}{102} & \multirow[t]{2}{*}{1.35} & \multirow[t]{2}{*}{0.179} \\
\hline & & Erkek & 51 & 17.54 & 5.77 & & & \\
\hline & \multirow{2}{*}{ Toplam } & $\mathrm{K} \mathrm{IZ}$ & 53 & 66.83 & 14.54 & \multirow[t]{2}{*}{102} & \multirow[t]{2}{*}{1.49} & \multirow[t]{2}{*}{0.138} \\
\hline & & Erkek & 51 & 62.19 & 17.01 & & & \\
\hline
\end{tabular}

Tablo 7'de ana dili Türkçe olan ortaokul öğrencilerinin DiSKSÖ puanlarında cinsiyet değişkeni açısından anlamlı bir farklılık olmadığı görülmektedir $t(102)=0.14$, $(p>0,05)$. Ölçeğin alt boyutları olan anlamlı ve ayırt edici dinleme/izleme stratejileri açısından da ana dili Türkçe olan ortaokul öğrencilerinin ölçekten aldıkları toplam puanların cinsiyet açısından anlamlı olarak farklılaşmadığı söylenebilir. Buna rağmen eleştirel dinleme/izleme stratejilerini kullanım sıklığı boyutu açısından ana dili Türkçe olan kız öğrencilerin lehine anlamlı bir farklılık olduğu görülmektedir $t(102)=0.15,(p<0,05)$. Bu bulgu ana dili Türkçe olan ortaokul öğrencilerinin dinleme/izleme stratejilerini kullanım sıklığı ile cinsiyet arasında anlamlı bir ilişkinin olmadığı ancak eleştirel dinleme/izleme stratejilerini kız öğrencilerin daha sıklıkla kullandığı şeklinde yorumlanabilir.

Ana dili Türkçe olmayan ortaokul öğrencilerinin DiSKS ölçeğinden aldıkları puanların cinsiyet açısından t-Testi puanları Tablo 8'de sunulmuştur.

Tablo 8.

Ana Dili Türkçe Olmayan Ortaokul Öğrencilerinin DiSKS Ölçeğinden Aldıkları Puanların Cinsiyet Açısından t-Testi Sonuçları

\begin{tabular}{llllccccc}
\hline & Boyut & Cinsiyet & $\mathrm{n}$ & $\bar{X}$ & $\mathrm{~S}$ & $\mathrm{sd}$ & $\mathrm{t}$ & $\mathrm{p}$ \\
\cline { 2 - 8 } & Eleştirel & Erkek & 59 & 22.22 & 5.40 & 104 & 2.56 & 0,012 \\
& Dinleme/Izleme & Kız & 47 & 19.44 & 5.70 & & & \\
Ana Dili & Anlamlı & Erkek & 59 & 25.18 & 5.55 & 104 & 2.08 & 0.040 \\
Türkçe & Dinleme/İzleme & Kız & 47 & 22.87 & 5.85 & & & \\
Olmayan & \multirow{2}{*}{ Ayırt Edici } & Erkek & 59 & 15.86 & 4.43 & 104 & 1.21 & 0.226 \\
& Dinleme/İzleme & Kız & 47 & 14.82 & 4.23 & & & \\
\cline { 2 - 8 } & \multirow{2}{*}{ Toplam } & Erkek & 59 & 60.08 & 12.90 & 104 & 2.27 & 0.025 \\
& Kız & 47 & 54.29 & 13.18 & & & \\
\hline
\end{tabular}

Tablo 8'de ana dili Türkçe olmayan ortaokul öğrencilerinin DiSKSÖ puanlarının cinsiyet açısından anlamlı olarak farklılaştığı görülmektedir $(104)=2.27,(p<0,05)$. Ölçeğin alt boyutları olan eleştirel ve anlamlı dinleme/izleme stratejileri açısından da ana dili Türkçe olmayan ortaokul öğrencilerinin puanlarının cinsiyet açısından anlamlı olarak erkek öğrencilerin lehine farklılaştığı söylenebilir. Buna rağmen ayırt edici dinleme/izleme stratejilerini kullanım sıklığı boyutu açısından ana dili Türkçe olmayan ortaokul öğrencileri arasında bir farklılaşma olmadığı ifade edilebilir $t(104)=1.21, \quad(p>0,07)$. Bu bulgu ana dili Türkçe olmayan ortaokul öğrencilerinin dinleme/izleme stratejilerini kullanım sıklığının cinsiyet açsısından erkek öğrencilerin lehine anlamlı olarak farklılaştığı ancak ayırt edici dinleme/izleme stratejileri açısından bir farklılaşma olmadığı şeklinde yorumlanabilir. 
Ortaokul öğrencilerinin DiSKS ölçeğinden aldıkları toplam puanların sınıf düzeyi açısından Anova Testi sonuçları Tablo 9'da sunulmuştur.

Tablo 9.

Ortaokul Öğrencilerinin DiSKS Ölçeğinden Aldıkları Toplam Puanların Sınıf Düzeyine Göre Anova Testi Sonuçları

\begin{tabular}{|c|c|c|c|c|c|c|c|c|c|c|c|}
\hline & $\begin{array}{c}\text { Sınıf } \\
\text { Düzeyi }\end{array}$ & $\mathrm{n}$ & $\bar{X}$ & SS & $\begin{array}{l}\text { Var. } \\
\text { Kay. }\end{array}$ & Kareler T. & sd & $\begin{array}{c}\text { Kareler } \\
\text { Ort. }\end{array}$ & $F$ & $p$ & $\begin{array}{l}\text { A. } \\
\text { Fark }\end{array}$ \\
\hline \multirow{5}{*}{ 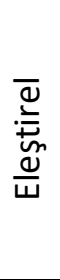 } & 5 & 57 & 15.50 & 6.08 & G. & 1204.04 & 3 & 401.34 & 15.99 & 0.000 & \multirow{5}{*}{$\begin{array}{l}5-6 \\
5-7 \\
5-8 \\
6-8\end{array}$} \\
\hline & 6 & 45 & 18.93 & 5.17 & G. İçi & 5167.94 & 206 & 25.08 & & & \\
\hline & 7 & 45 & 19.62 & 4.75 & Toplam & 6371.98 & 209 & & & & \\
\hline & 8 & 63 & 21.79 & 3.84 & & & & & & & \\
\hline & Top. & 210 & 19.00 & 5.52 & & & & & & & \\
\hline \multirow{5}{*}{$\frac{\overline{\bar{\varepsilon}}}{\frac{\bar{\sigma}}{\frac{\pi}{\varepsilon}}}$} & 5 & 57 & 22.01 & 6.79 & G. & 1534.28 & 3 & 511.42 & 14.00 & 0.000 & \multirow{5}{*}{$\begin{array}{l}5-7 \\
5-8 \\
6-8 \\
7-8\end{array}$} \\
\hline & 6 & 45 & 23.42 & 6.54 & G. İçi & 7523.54 & 206 & 36.5 & & & \\
\hline & 7 & 45 & 25.91 & 6.25 & Toplam & 9057.82 & 209 & & & & \\
\hline & 8 & 63 & 28.74 & 4.62 & & & & & & & \\
\hline & Top. & 210 & 25.17 & 6.58 & & & & & & & \\
\hline \multirow{5}{*}{ 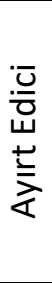 } & 5 & 57 & 13.77 & 5.46 & G. & 1073.58 & 3 & 357.86 & 17.18 & 0.000 & \multirow{5}{*}{$\begin{array}{l}5-6 \\
5-7 \\
5-8 \\
6-8\end{array}$} \\
\hline & 6 & 45 & 16.02 & 4.51 & G. İçi & 4290.89 & 206 & 20.8 & & & \\
\hline & 7 & 45 & 17.60 & 4.53 & Toplam & 5364.48 & 209 & & & & \\
\hline & 8 & 63 & 19.60 & 3.62 & & & & & & & \\
\hline & Top. & 210 & 16.82 & 5.06 & & & & & & & \\
\hline \multirow{5}{*}{$\begin{array}{l}\frac{\varepsilon}{\sigma} \\
\frac{\sigma}{0} \\
\stackrel{0}{\circ}\end{array}$} & 5 & 57 & 51.29 & 15.99 & G. & 11145.57 & 3 & 3715.19 & 21.24 & 0.000 & \multirow{5}{*}{$\begin{array}{l}5-6 \\
5-7 \\
5-8 \\
6-8 \\
7-8\end{array}$} \\
\hline & 6 & 45 & 58.37 & 13.49 & G. İçi & 36017.42 & 206 & 174.84 & & & \\
\hline & 7 & 45 & 63.13 & 13.60 & Toplam & 47162.99 & 209 & & & & \\
\hline & 8 & 63 & 70.14 & 9.43 & & & & & & & \\
\hline & Top. & 210 & 61.00 & 15.02 & & & & & & & \\
\hline
\end{tabular}

Tablo 9'da ifade edildiği üzere DiSKS ölçeğinden alınan puanlar gruplar arasında anlamlı olarak farklılaşmaktadır $(\mathrm{F}=21.249 ; \mathrm{p}<0.01)$. Anlamlı farklılığın hangi gruplar arasında olduğunu belirlemek için homojenlik testi (Levene testi $=2.287, p=0.080$ ) göz önüne alınarak uygulanan Tukey testi sonuçlarına göre eleştirel dinleme/izleme boyutu açısından 5. Sınıf öğrencilerinin 6 ve 7. Sınıf öğrencilerinden, 6 . Sınıf öğrencilerinin ise 8 . Sınıf öğrencilerinden daha düşük sıklıkta dinleme/izleme stratejilerini kullandıkları ifade edilebilir. Anlamlı dinleme/izleme boyutu açısından 5 . Sınıf öğrencilerinin 7 ve 8 . Sınıf öğrencilerinden, 6 ve 7 . Sınıf öğrencilerinin de 8 . Sınıf öğrencilerinden daha düşük sıkııta dinleme/izleme stratejilerini kullandıkları ifade edilebilir. Ayırt edici dinleme/izleme boyutu açısından 5. Sınıf öğrencilerinin 6,7 ve 8 . Sınıf öğrencilerinden, 6 . Sınıf öğrencilerinin de 8 . Sınıf öğrencilerinden daha düşük sıklıkta dinleme/izleme stratejilerini kullandıkları ifade edilebilir.

DiSKS ölçeğinin tamamı açısından ise 5. Sınıf öğrencilerinin 6,7 ve 8. Sınıf öğrencilerinden, 6 ve 7 . Sınıf öğrencilerinin de 8 . Sınıf öğrencilerinden daha düşük sıklıkta dinleme/izleme stratejilerini kullandıkları ifade edilebilir.

Ana dili Türkçe olan ortaokul öğrencilerinin DiSKS ölçeğinden aldıkları toplam puanların sınıf düzeyi açısından Anova Testi sonuçları Tablo 10'da sunulmuştur. 
Ortaokul Öğrencilerinin Dinleme/İzleme Stratejilerini Kullanma Durumları; Ana Dili Açısından Bir Karşılaştırma

Tablo 10.

Ana Dili Türkçe Olan Ortaokul Öğrencilerinin DisKS Ölçeğinden Aldıkları Toplam Puanların Sınıf Düzeyi Açısından Anova Testi Sonuçları

\begin{tabular}{|c|c|c|c|c|c|c|c|c|c|c|c|}
\hline & $\begin{array}{c}\text { Sınıf } \\
\text { Düzeyi }\end{array}$ & $\mathrm{n}$ & $\bar{X}$ & SS & $\begin{array}{l}\text { Var. } \\
\text { Kay. }\end{array}$ & Kareler T. & sd & $\begin{array}{c}\text { Kareler } \\
\text { Ort. }\end{array}$ & $\mathrm{F}$ & $p$ & $\begin{array}{l}\text { A. } \\
\text { Fark }\end{array}$ \\
\hline \multirow{5}{*}{ 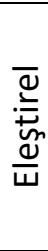 } & 5 & 29 & 17.82 & 6.60 & G. Arası & 1385.44 & 3 & 461.81 & 16.34 & 0.000 & \multirow{5}{*}{$\begin{array}{l}5-6 ; \\
5-7 ; \\
5-8 ; \\
6-8 ;\end{array}$} \\
\hline & 6 & 23 & 23.43 & 5.59 & G. İçi & 2825.94 & 100 & 28.25 & & & \\
\hline & 7 & 22 & 24.45 & 5.30 & Toplam & 4211.34 & 103 & & & & \\
\hline & 8 & 30 & 27.33 & 3.35 & & & & & & & \\
\hline & Top. & 104 & 23.21 & 6.39 & & & & & & & \\
\hline \multirow{5}{*}{$\frac{\overline{\bar{\varepsilon}}}{\frac{\pi}{\frac{\pi}{\varepsilon}}}$} & 5 & 29 & 21.34 & 7.20 & G. Arası & 1315.27 & 3 & 438.42 & 10.91 & 0.000 & \multirow{5}{*}{$\begin{array}{l}5-7 \\
5-8 ; \\
6-8 ; \\
7-8\end{array}$} \\
\hline & 6 & 23 & 25.13 & 7.62 & G. İçi & 4015.48 & 100 & 40.15 & & & \\
\hline & 7 & 22 & 27.95 & 5.93 & Toplam & 5330.75 & 103 & & & & \\
\hline & 8 & 30 & 30.43 & 4.32 & & & & & & & \\
\hline & Top. & 104 & 26.20 & 7.19 & & & & & & & \\
\hline \multirow{5}{*}{ 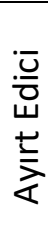 } & 5 & 29 & 13.93 & 5.88 & G. Arası & 965.11 & 3 & 321.70 & 16.28 & 0.000 & \multirow{5}{*}{$\begin{array}{l}5-7 \\
5-8 \\
6-8\end{array}$} \\
\hline & 6 & 23 & 17.56 & 4.64 & G. İçi & 1975.34 & 100 & 19.75 & & & \\
\hline & 7 & 22 & 20.27 & 3.76 & Toplam & 2940.46 & 103 & & & & \\
\hline & 8 & 30 & 21.53 & 2.82 & & & & & & & \\
\hline & Top. & 104 & 18.26 & 5.34 & & & & & & & \\
\hline \multirow{5}{*}{$\begin{array}{l}\frac{\varepsilon}{\frac{1}{\pi}} \\
\frac{0}{0} \\
\frac{1}{\circ}\end{array}$} & 5 & 29 & 50.37 & 16.25 & G. Arası & 10148.45 & 3 & 3382.81 & 21.30 & 0.000 & \multirow{5}{*}{$\begin{array}{l}5-6 ; \\
5-7 ; \\
5-8 ; \\
6-8 ;\end{array}$} \\
\hline & 6 & 23 & 63.21 & 13.71 & G. İçi & 15879.19 & 100 & 158.79 & & & \\
\hline & 7 & 22 & 69.36 & 11.93 & Toplam & 26027.65 & 103 & & & & \\
\hline & 8 & 30 & 75.76 & 6.80 & & & & & & & \\
\hline & Top. & 104 & 64.55 & 15.89 & & & & & & & \\
\hline
\end{tabular}

Tablo 10'da ifade edildiği üzere ana dili Türkçe olan öğrencilerin DiSKS ölçeğinden aldıkları puanlar gruplar arasında anlamlı olarak farklılaşmaktadır $(F=21.303 ; p<0.01)$. Anlamlı farklıı̆ı̆ hangi gruplar arasında olduğunu belirlemek için homojenlik testi (Levene testi=4.704, p=0.004) göz önüne alınarak uygulanan Tamhane testi sonuçlarına göre Eleştirel Dinleme/izleme boyutu açısından 5. Sınıf öğrencilerinin 6, 7 ve 8. Sınıf öğrencilerinden, 6 . Sınıf öğrencilerinin ise 8. Sınıf öğrencilerinden daha düşük sıklıkta dinleme/izleme stratejilerini kullandıkları ifade edilebilir. Anlamlı dinleme/izleme boyutu açısından, ana dili Türkçe olan, 5. Sınıf öğrencilerinin 7 ve 8 . Sınıf öğrencilerinden, 6 ve 7 . Sınıf öğrencilerinin de 8. Sınıf öğrencilerinden daha düşük sıklıkta dinleme/izleme stratejilerini kullandıkları ifade edilebilir. Ayırt Edici Dinleme/İzleme boyutu açısından, ana dili Türkçe olan, 5. Sınıf öğrencilerinin 6,7 ve 8. Sınıf öğrencilerinden, 6 . Sınıf öğrencilerinin de 8. Sınıf öğrencilerinden daha düşük sıklıkta dinleme/izleme stratejilerini kullandıkları ifade edilebilir.

DiSKS ölçeğinin tamamı açısından ise, ana dili Türkçe olan, 5. Sınıf öğrencilerinin 6,7 ve 8 . Sınıfla öğrencilerinden, 6 ve 7. Sınıf öğrencilerinin de 8. Sınıf öğrencilerinden daha düşük sıklıkta dinleme/izleme stratejilerini kullandıkları ifade edilebilir.

Ana dili Türkçe olmayan ortaokul öğrencilerinin DiSKS ölçeğinden aldıkları toplam puanların sınıf düzeyi açısından Anova Testi sonuçları Tablo 11'de sunulmuştur.

Tablo 11.

Ana Dili Türkçe Olmayan Ortaokul Öğrencilerinin DisKS Ölçeğinden Aldıkları Toplam Puanların Sınıf Düzeyi Açısından Anova Testi Sonuçları

\begin{tabular}{|c|c|c|c|c|c|c|c|c|c|c|c|}
\hline & $\begin{array}{c}\text { Sinıf } \\
\text { Düzeyi }\end{array}$ & $\mathrm{n}$ & $\bar{X}$ & ss & $\begin{array}{l}\text { Var. } \\
\text { Kay. }\end{array}$ & Kareler T. & sd & $\begin{array}{c}\text { Kareler } \\
\text { Ort. }\end{array}$ & $\mathrm{F}$ & $p$ & $\begin{array}{c}\text { A. } \\
\text { Fark }\end{array}$ \\
\hline \multirow{2}{*}{ 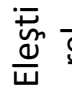 } & 5 & 28 & 18.46 & 7.04 & G. Arası & 378.80 & 3 & 126.26 & 4.27 & 0.007 & \multirow{2}{*}{$5-8$} \\
\hline & 6 & 22 & 20.27 & 5.46 & G. İçi & 3016.18 & 102 & 29.57 & & & \\
\hline
\end{tabular}




\begin{tabular}{|c|c|c|c|c|c|c|c|c|c|c|c|}
\hline & 7 & 23 & 21.34 & 4.91 & Toplam & 3394.99 & 105 & & & & \\
\hline & 8 & 33 & 23.36 & 4.02 & & & & & & & \\
\hline & Top. & 106 & 20.99 & 5.68 & & & & & & & \\
\hline & 5 & 28 & 22.71 & 6.41 & G. Arası & 506.99 & 3 & 168.99 & 5.74 & 0.001 & \\
\hline & 6 & 22 & 21.63 & 4.72 & G. İçi & 3001.27 & 102 & 29.42 & & & \\
\hline$\frac{\frac{c}{0}}{\pi}$ & 7 & 23 & 23.95 & 6.04 & Toplam & 3508.27 & 105 & & & & 5-8; \\
\hline & 8 & 33 & 27.21 & 4.39 & & & & & & & \\
\hline & Top. & 106 & 24.16 & 5.78 & & & & & & & \\
\hline & 5 & 28 & 13.60 & 5.10 & G. Arası & 312.36 & 3 & 104.12 & 6.31 & 0.001 & \\
\hline$\frac{\overline{\underline{y}}}{0}$ & 6 & 22 & 14.40 & 3.83 & G. İçi & 1681.19 & 102 & 16.48 & & & \\
\hline & 7 & 23 & 15.04 & 3.68 & Toplam & 1993.55 & 105 & & & & 5-8; \\
\hline & 8 & 33 & 17.84 & 3.40 & & & & & & & $6-8$ \\
\hline & Top. & 106 & 15.40 & 4.35 & & & & & & & \\
\hline & 5 & 28 & 52.25 & 15.96 & G. Arası & 3030.16 & 3 & 1010.05 & 6.64 & 0.000 & \\
\hline & 6 & 22 & 53.31 & 11.49 & G. İçi & 15504.29 & 102 & 152.00 & & & \\
\hline 工 & 7 & 23 & 57.17 & 12.58 & Toplam & 18534.46 & 105 & & & & 3-8; \\
\hline & 8 & 33 & 65.03 & 8.59 & & & & & & & \\
\hline & Top. & 106 & 57.51 & 13.28 & & & & & & & \\
\hline
\end{tabular}

Tablo $11^{\prime}$ de ifade edildiği üzere ana dili Türkçe olmayan öğrencilerin DiSKS ölçeğinden aldıkları puanlar gruplar arasında anlamlı olarak farklılaşmaktadır ( $F=6.645 ; p<0.01)$. Anlamlı farklıı̆ıın hangi gruplar arasında olduğunu belirlemek için homojenlik testi (Levene testi=5.157, p=0.002) göz önüne alınarak uygulanan Tamhane testi sonuçlarına göre eleştirel dinleme/izleme boyutu açısından 5. Sınıf öğrencilerinin 8. Sınıf öğrencilerinden daha düşük sıklıkta dinleme/izleme stratejilerini kullandıkları ifade edilebilir. Anlamlı dinleme/izleme boyutu açısından, ana dili Türkçe olmayan, 5 ve 6. Sınıf öğrencilerinin 8. Sınıf öğrencilerinden daha düşük sıklıkta dinleme/izleme stratejilerini kullandıkları ifade edilebilir. Ayırt edici dinleme/izleme boyutu açısından, ana dili Türkçe olmayan, 5 ve 6. Sınıf öğrencilerinin 8 . Sınıf öğrencilerinden daha düşük sıklıkta dinleme/izleme stratejilerini kullandıkları ifade edilebilir.

DiSKS ölçeğinin tamamı açısından ise, ana dili Türkçe olmayan 5 ve 6 . Sınıf öğrencilerinin 8. Sınıf öğrencilerinden daha düşük sıkııta dinleme/izleme stratejilerini kullandıkları ifade edilebilir.

Ana dili Türkçe olmayan ortaokul öğrencilerinin dinleme/izleme stratejilerini kullanım sıklıkları açısından diğer sınıf düzeyleri arasında anlamlı bir farklılaşma olmadığı söylenebilir.

\section{Tartışma ve Sonuç}

Araştırma sonuçlarına göre dinleme/izleme stratejileri açısından ana dili Türkçe olan öğrencilerin ana dili Türkçe olmayan öğrencilere göre dinleme/izleme stratejilerini daha sık kullandıkları ifade edilebilir. Buna ek olarak ana dili Türkçe olmayan öğrencilerin eleştirel, anlamlı ve ayırt edici dinleme/izleme stratejilerini ana dili Türkçe olan öğrencilere göre daha az kullandıkları sonucuna ulaşılımışır.

Ana dili Türkçe olan ortaokul öğrencilerinin dinleme/izleme stratejilerini kullanım sıklığı ile cinsiyet arasında anlamlı bir ilişkinin olmadığı belirlenmiştir. Buna rağmen eleştirel dinleme/izleme stratejilerini kız öğrencilerin daha sıklıkla kullandığı sonucuna ulaşılmıştır. Diğer taraftan ana dili Türkçe olmayan erkek ortaokul öğrencilerinin dinleme/izleme stratejilerini kız öğrencilerden daha sık kullandığı belirlenmiştir. Bununla birlikte ana dili Türkçe olmayan kız ve erkek ortaokul öğrencileri arasında ayırt edici dinleme/izleme stratejileri açısından bir farklılaşma olmadığı tespit edilmiştir.

Ortaokul öğrencilerinin dinleme/izleme stratejilerini kullanım sıkıkları sınıf düzeyi göre değişiklik göstermektedir. Eleştirel dinleme/izleme boyutu açısından 5. Sınıf öğrencilerinin 6 ve 7. Sınıf öğrencilerinden, 6. Sınıf öğrencilerinin de 8. Sınıf öğrencilerinden daha düşük sıklıkta dinleme/izleme stratejilerini kullandıkları sonucuna ulaşıımışıı. Buna ek olarak anlamlı dinleme/izleme boyutu açısından 5. Sınıf öğrencilerinin 7 ve 8. Sınıf öğrencilerinden, 6 ve 7 . 
öğrencilerinin de 8. Sınıf öğrencilerinden daha düşük sıklıkta dinleme/izleme stratejilerini kullandıkları görülmüştür. Ayırt edici dinleme/izleme boyutu açısından 5. Sınıf öğrencilerinin 6,7 ve 8 . Sınıf öğrencilerinden, 6 . Sınıf öğrencilerinin de 8 . Sınıf öğrencilerinden daha düşük sıklıkta dinleme/izleme stratejilerini kullandıkları belirlenmiştir. Bunula birlikte genel olarak 5. Sınıf öğrencilerinin 6,7 ve 8 . Sınıf öğrencilerinden, 6 ve 7. Sınıf öğrencilerinin de 8. Sınıf öğrencilerinden daha düşük sıklıkta dinleme/izleme stratejilerini kullandıkları soncuna ulaşıımıştır.

Ana dili Türkçe olan ortaokul öğrencilerinin dinleme/izleme stratejilerini kullanım sıklıkları sınıf düzeyine göre farklılaşmaktadır. Eleştirel dinleme/izleme boyutu açısından 5. Sınıf öğrencilerinin 6, 7 ve 8. Sınıf öğrencilerinden, 6. Sınıf öğrencilerinin de 8. Sınıf öğrencilerinden daha düşük sıklıkta dinleme/izleme stratejilerini kullandıkları belirlenmiştir. Anlamlı dinleme/izleme boyutu açısından 5 . Sınıf öğrencilerinin 7 ve 8. Sınıf öğrencilerinden, 6 ve 7. Sınıf öğrencilerinin de 8. Sınıf öğrencilerinden daha düşük sıklıkta dinleme/izleme stratejilerini kullandıkları sonucuna ulaşılmıştır. Ayırt edici dinleme/izleme boyutu açısından 5. Sınıf öğrencilerinin 6,7 ve 8 . Sınıf öğrencilerinden, 6 . Sınıf öğrencilerinin de 8. Sınıf öğrencilerinden daha düşük sıklıkta dinleme/izleme stratejilerini kullandıkları tespit edilmiştir. Bunula birlikte genel olarak ana dili Türkçe olan 5. Sınıf öğrencilerinin 6,7 ve 8 . Sınıf öğrencilerinden, 6 ve 7. Sınıf öğrencilerinin de 8. Sınıf öğrencilerinden daha düşük sıklıkta dinleme/izleme stratejilerini kullandıkları sonucuna ulaşıımıştır.

Ana dili Türkçe olmayan ortaokul öğrencilerinin dinleme/izleme stratejilerini kullanım sıklıkları sınıf düzeyine göre farklılaşmaktadır. Eleştirel dinleme/izleme boyutu açısından 5. Sınıf öğrencilerinin 8. Sınıf öğrencilerinden daha düşük sıklıkta dinleme/izleme stratejilerini kullandıkları belirlenmiştir. Anlamlı dinleme/izleme boyutu açısından, ana dili Türkçe olmayan 5 ve 6 . Sınıf öğrencilerinin 8. Sınıf öğrencilerinden daha düşük sıklıkta dinleme/izleme stratejilerini kullandıkları tespit edilmiştir. Ayırt edici dinleme/izleme boyutu açısından, ana dili Türkçe olmayan 5 ve 6 . Sınıf öğrencilerinin 8. Sınıf öğrencilerinden daha düşük sıklıkta dinleme/izleme stratejilerini kullandıkları belirlenmiştir. Bunula birlikte genel olarak ana dili Türkçe olmayan 5 ve 6 . Sınıf öğrencilerinin 8 . Sınıf öğrencilerinden daha düşük sıklıkta dinleme/izleme stratejilerini kullandıkları sonucuna ulaşıımıştır.

Dinleme becerisinin gelişiminde zihinsel ve kalıtımsal faktörlerle birlikte çevresel bir faktör olan ana dili de önemli bir etkiye sahiptir. Konuşulan dilin yapısı ve çevrede maruz kalınan dil etkinleri de bireyin dinleme becerisinin gelişimini etkilemektedir. Özellikle ana dili farklı olan ve Türkçeyi ikinci dil olarak öğrenen öğrencilerin dil becerileri açısından doğal olarak pek çok sorunla karşılaştığı bilinmektedir (Aslan, 2018; Kan ve Yeşiloğlu, 2017; Pekgenç, 2019; Susar, 2019; Yıldız ve Kızıltaş, 2018). Araştırma sürecinde ulaşılan sonuçlar da bu durumu destekler nitelikledir. illkokul ve ortaokul öğrencilerinin dinleme, dinlediğini anlama ve akademik başarıları üzerine yapılmış olan çalışmalar (Çetingöz ve Açıkgöz, 2009; Arslan, 2017; Ceran, 2015; Fidan ve Gerçek, 2017; Karabacak, 2014; Kocaadam, 2011) dinleme stratejileri kullanmanın öğrencilerin dinlediğini fark etmesi ve anlaması üzerinde olumlu sonuçlar verdiğini göstermektedir. Ana dili Türkçe olmayan öğrencileri dinleme/izleme stratejilerini ana dili Türkçe olan çocuklara göre daha az sıklıkla kullanmaktadırlar. Bu doğrultuda ana dili Türkçe olmayan ortaokul öğrencilerinin dinleme/izleme stratejilerinin desteklenmesi ve iş birliğine dayalı yöntemlerle üstbilişsel dinleme becerilerinin desteklenmesi önerilmektedir.

DiSKS ölçeğinin tamamı açısından 5. Sınıf öğrencilerinin 6, 7 ve 8. Sınıf öğrencilerinden, 6 ve 7. Sınıf öğrencilerinin 8. Sınıf öğrencilerinden daha düşük sıklıkta dinleme/izleme stratejilerini kullandıkları ifade edilebilir. Bununla birlikte ana dili Türkçe olmayan 5. Sınıf ortaokul öğrencilerinin dinleme/izleme stratejilerini 8. Sınıf öğrencilerinden daha az kullandığı belirlenmiştir. Diğer sınıf düzeyleri açısından ise anlamlı bir farklılık bulunmamaktadır. Ana dili Türkçe olan ortaokul öğrencilerinin sınıf düzeyi açısından neredeyse her sınıf için farklı düzeyde dinleme/izleme stratejilerini kullandıkları görülürken ana dili Türkçe olmayan ortaokul öğrencileri arasında sadece 5 ile 8. Sınıf öğrencileri arasında farklılaşma olması aynı eğitim sürecinde olmalarına rağmen dinleme/izleme becerilerinde benzer ilerlemeyi sergileyemedikleri şeklinde değerlendirilebilir. Fidan (2019) ortaokul öğrencilerinin Türkçe derslerinde eleştirel dinleme stratejilerini kullanma durumlarını çeşitli değişkenler yönünden incelediği çalışmasında sınıf değişkeni açısından altıncı 6.sınıf öğrencilerinin 7 ve 8. Sınıf öğrencilerine göre daha sık kullandıkları sonucuna ulaşmıştır. 
Araştırmada ana dili Türkçe olan ortaokul öğrencilerinin dinleme/izleme stratejilerini kullanım sıklığının cinsiyet açısından anlamlı bir farklılık göstermediği sonucuna ulaşılmıştır. Ana dili Türkçe olmayan ortaokul öğrencileri arasında erkek öğrencilerin dinleme/izleme stratejilerini kullanım sıklığının kız öğrencilere göre daha yüksek olduğu tespit edilmiştir. Demircan ve Aydın (2019) tarafından yapılan araştırmada ise kız öğrencilerin dinleme öz yeterlik algılarının erkek öğrencilerden daha yüksek olduğu sonucuna ulaşıımış ve kız öğrencilerin dil gelişimi açısından erkeklerden daha ilerde olduğu vurgulanarak bu durumun beklenen bir sonuç olabileceği ifade edilmiştir. Ayrıca Fidan (2019) kız öğrencilerin erkek öğrencilere göre dinleme stratejilerini kullanma sıklıklarının daha fazla olduğu sonucuna varmış, kız öğrencilerin bu tür uygulamalarda daha fazla istekli olduğuna vurgu yapmıştır. Bu doğrultuda ortaokul öğrencilerinin dinleme/izleme stratejilerini kullanım sıklığı ile dinleme/izleme öz yeterlikleri arasındaki ilişkinin sorgulanması önerilmektedir.

Araştırma sonuçları genel olarak ana dili Türkçe olan ve olmayan ortaokul öğrencilerinin dinleme/izleme stratejilerini kullanma sıklıklarının farklı olduğunu göstermektedir. Sınıf düzeyi açısından ana dili Türkçe olan ortaokul öğrencilerinin dinleme/izleme stratejilerini kullanma sıklıkları anlamlı olarak farklıık göstermezken ana dili Türkçe olmayan ortaokul öğrencilerinin dinleme/izleme stratejilerini kullanma sıklıkları anlamlı olarak farklılaşmaktadır. Bu durum ana dili Türkçe olmayan ortaokul öğrencilerinin dinleme/izleme becerileri açısından ana dili Türkçe olan öğrencilerden farklı bir gelişim süreci takip ettiğinin bir göstergesi olarak değerlendirilebilir. Bu nedenle erken yaşlardan itibaren ana dili Türkçe olmayan öğrencilerin dinleme/izleme stratejilerini destekleyecek programlara dâhil edilmesi önerilmektedir.

\section{Kaynaklar}

Akyol, H. (2016). Türkçe öğretim yöntemleri (8.Baskı). Ankara: Pegem Akademi.

Arslan, Ş. (2017). Dinlediklerini özetlemede hikâye haritası yönteminin etkisi (Yayımlanmamış Yüksek Lisans Tezi). Bartın Üniversitesi, Eğitim Bilimleri Enstitüsü, Bartın.

Aslan, A. (2018). Türkçenin yeterince etkin ve güzel konuşulmadığı yerlerde ilkokuma yazma öğretiminde öğretmenlerin karşılaştığı sorunlar (Ağrı ili örneği) (Yayımlanmamış Yüksek Lisans Tezi). Ağrı Ibrahim Çeçen Üniversitesi, Sosyal Bilimler Enstitüsü, Ağrı.

Bozorgian, H. (2012). Listening skill requires a further look into second/foreign language learning. ISRN Education, 2012, s. 1 - 10. doi:10.5402/2012/810129.

Büyüköztürk, Ş., Kılıç Çakmak, E., Akgün, Ö. E., Karadeniz, ş. ve Demirel, F. (2018). Bilimsel Araştırma Yöntemleri (25.Baskı). Ankara: Pegem Akademi.

Casbergue, R. M. ve Harris, K. (1996). Listening and literacy: audiobooks in the reading program. Reading Horizons: A Journal of Literacy and Language Arts, 37(1), s. 48-59.

Ceran, D. (2015). Seçici dinleme ile not alarak dinleme yöntemlerinin altıncı sınıf öğrencilerinin dinlediğini anlama becerisine etkisi. Zeitschriftfür die Welt der Türken, 7(1), 205-219.

Creswell, J.W. (2013). Educational research: Planning, conducting and evaluating quantitative and qualitative research(4th ed.). Boston: Pearson.

Çetingöz, D. ve Açıkgöz, K. (2009). Not alma stratejisinin öğretiminin tarih başarısı ve hatırda tutma üzerindeki etkileri. Kuram ve Uygulamada Eğitim Yönetimi, 60(60), 577-600.

Çokluk, Ö. S., Şekercioğlu, G. ve Büyüköztürk, S. (2012). Sosyal bilimler için çok değişkenli istatistik: spss ve lisrel uygulamaları. Ankara: Pegem Akademi Yayıncılık.

Demircan, U. ve Aydın, ì. S. (2019). Ortaokul öğrencilerinin dinleme/izleme öz-yeterliklerinin çeşitli değişkenlere göre incelenmesi. Kastamonu Eğitim Dergisi, 27(4), 1517-1527.

Doğan, B. ve Erdem, í. (2017). Ortaokul öğrencilerinin dinleme/izleme stratejileri kullanım sıklığı ölçeğinin geçerlik-güvenirlik çalışması. E-Uluslararası Eğitim Araştırmaları Dergisi, 8(1), s.6481. Doi: $10.19160 / 5000204360$

Durmuş, N. (2013). Ilköğretim 2. sınıf öğrencilerinin dinleme becerilerinin geliştirilmesinde çocuk edebiyatı ürünlerinin etkisi (Yayımlanmamış Yüksek Lisans Tezi). Uludağ Üniversitesi, Eğitim Bilimleri Enstitüsü, Bursa.

Emiroğlu, S. ve Pınar, F. N. (2013). Dinleme becerisinin diğer beceri alanlarıyla ilişkisi. Turkish Studies. 8(4). s. 769-782. 
Fidan, D. ve Gerçek, Ş. (2017). 2017 Türkçe öğretim programında ve ortaokul Türkçe 5. sınıf ders kitabında özetleme becerisi. Current Debates in Education. Volume 5. IJOPEC Publication Limited.

Fidan, M. (2019). Ortaokul öğrencilerinin Türkçe dersinde kullandıkları eleştirel dinleme stratejilerinin çeşitli değiş̧enler yönünden incelenmesi. Rumeli'de Dil ve Edebiyat Araştırmaları Dergisi, (15), s. 79-98.

Feyten, C. M. (1991). The power of listening ability: An overlooked dimension in language acquisition. The modern language journal, 75(2), s. 173-180.

Fisher, D. ve McDonald, N. (2001). The intesection between music and early literacy instruction: listening to literacy!. Reading Improvement, 38(3), s. 106-116.

Güneş, F. (2007). Türkçe Öğretimi ve Zihinsel Yapılandırma (1.Baskı). Ankara: Nobel Yayın Dağıtım.

Hampleman, R. S. (1958). Comparison of listening and reading comprehension ability of fourth and sixth grade pupils. Elementary English, 35(1), s. 49-53.

Kan, M. O. ve Yeşiloğlu, F. (2017). Illk okuma yazma öğretiminde izlenen aşamalarda iki dilli çocukların yaşadıkları sorunlar ve bu sorunlara dair çözüm önerileri. Ana Dili Eğitimi Dergisi, 5(3), s. 519533.

Karabacak, E. (2014). Seçici dinleme eğitiminin 6. sınıf öğrencilerinin dinleme becerisi üzerindeki etkisi (Yayımlanmamış Yüksek Lisans Tezi). Erbakan Üniversitesi, Eğitim Bilimleri Enstitüsü, Konya.

Kocaadam, D. (2011). Not alarak dinleme eğitiminin ilköğretim 7. sınıf öğrencilerinin dinleme becerisi üzerindeki etkisi. (Yayımlanmamış Yüksek Lisans Tezi). Gazi Üniversitesi, Eğitim Bilimleri Enstitüsü, Ankara.

Koç, C. ve Arslan A. (2017). Ortaokul öğrencilerinin akademik öz yeterlik algıları ve okuma stratejileri bilişüstü farkındalıkları. YYÜ Eğitim Fakültesi Dergisi, 14(1), s. 745-778.

Lundsteen, S. W. (1979). Listening: Its Impact on reading and the other Language arts (Rev.Ed.) Urbana IL:National Counsel of Teachers of English.

Mackay, I. (1997). Dinleme Becerisi (çev. A. Bora ve O. Cankoçak). Ankara: Ilkkaynak Kültür ve Sanat Ürünleri.

Özbay, M. (2007). Türkçe Özel Öğretim Yöntemleri II. (2. Basım). Ankara: Öncü Kitap.

Özbay, M. (2009). Anlama Teknikleri-ll Dinleme eğitimi. Ankara: Öncü Kitap.

Pekgenç, Y. (2019). Sınıf öğretmenlerinin iki dilli sınıflarda yaşadığı eğitsel ve iletişimsel sorunlara ilişkin görüşleri (Yayımlanmamış Yüksek Lisans Tezi). Dicle Üniversitesi, Eğitim Bilimleri Enstitüsü. Diyarbakır.

Sadiku, L. M. (2015). The importance of four skills reading, speaking, writing, listening in a lesson hour. European Journal of Language and Literature, 1(1), s. 29-31.

Shanahan, T., MacArthur, C. A., Graham, S. ve Fitzgerald, J. (2006). Relations among oral language, reading, and writing development. Handbook of writing research, s. 171-183.

Snow, C. E., Tabors, P. O., Nicholson, P. A., ve Kurland, B. F. (1995). SHELL: Oral language and early literacy skills in kindergarten and first-grade children. Journal of Research in Childhood education, 10(1), s. 37-48.

Susar, F. (2019). Ana dili Türkçe olmayan öğrencilerde okul öncesi eğitimin ilk okuma yazma öğrenme sürecine etkisi. Pamukkale Üniversitesi Eğitim Fakültesi Dergisi, 48, s. 1-20.

Temizyürek, F. (2007). Illköğretim ikinci kademede konuşma becerisinin geliştirilmesi. Ankara Üniversitesi Eğitim Bilimleri Fakültesi Dergisi, 40(2), s. 113-131.

Şahin, C. (2015). Ortaokul öğrencilerinin dinleme becerilerinin geliştirilmesinde kısa filmlerin etkisi. Dil ve Edebiyat Eğitimi Dergisi, 10, s. 66-79.

Wolvin, A. ve Coakley, C. G. (1996). Listening. (5. Basım). Mc Graw Hill, Boston.

Yalçınkaya, F., Muluk, N. B. ve Şahin, S. (2009). Effects of listening ability on speaking, writing and reading skills of children who were suspected of auditory processing difficulty. International journal of pediatric otorhinolaryngology, 73(8), s. 1137-1142. 
Yıldız, M. ve Kızıltaş, Y. (2018). The attitudes of secondary school students toward school and reading: a comparison in terms of mother tongue, gender and class level. International Journal of Education and Literacy Studies, 6(1), s. 27-37.

\section{Extended Abstract}

\section{Introduction}

Listening skills begin to develop in the womb. Considering the development areas of language skills from birth, it can be stated that listening skill is important both in terms of other development areas and in the development of speaking, reading and writing skills, which are other language skills (Emiroğlu \& Pınar, 2013; Sadiku, 2015; Shanahan, MacArthur, Graham \& Fitzgerald, 2006 ;Temizyürek, 2007).

Moore (2001) states that listening consists of three stages: attention, auditory perception and listening comprehension, and these stages involve an active process in which they work together (Akyol 2016, pp.3). In addition, it is stated in the related literature that listening skills in the definitions cover hearing, attention, auditory perception, listening and listening comprehension processes (Akyol, 2016; Güneş, 2007; Lundsteen, 1979; Moore, 2001; Özbay, 2009). In this sense, it can be said that listening expresses a complex mental process that starts with hearing and results in listening comprehension, and the listening / viewing strategies employed in this process have an important effect in maximizing the process of establishing meaning.

The aim of this study is to determine frequency of using the listening / viewing strategies of secondary school students whose mother tongue is Turkish and mother tongue is not Turkish. In order for the individual to understand and react to what is happening in daily and academic life, needs an effective listening / viewing skill. In addition, it can be stated that the individual's listening / viewing skills and strategies used in this skill cover a critical process for a qualified learning. The process of developing listening / watching skills of children whose mother tongue is not Turkish may follow a different development process than children whose mother tongue is Turkish.

Based on this point, the main subject of the research is to determine the frequency of secondary school students whose mother tongue is Turkish and not using listening / viewing strategies. For this basic purpose, answers to the following questions were sought;

1. What is the frequency of secondary school students using listening / watching strategies?

2. Do the frequency of using listening / viewing strategies of secondary school students whose mother tongue is Turkish and whose mother tongue is not Turkish differ significantly?

3. Do the frequency of secondary school students using listening / viewing strategies differ significantly in terms of gender?

4. Do the frequency of secondary school students using listening / viewing strategies differ significantly in terms of grade level?

\section{Method}

Frequency of using the listening / viewing strategies of secondary school students whose mother tongue is Turkish and mother tongue is not Turkish has been analyzed with a descriptive perspective in the screening model. For this purpose, 210 secondary school students whose mother tongue is Turkish and mother tongue is not Turkish are in the sample of the study. Convenience sampling method was used to determine the sample of the research.

The data in the study were obtained from secondary schools in Sivas Province in the spring term of 2018-2019 academic year. In the data collection process, scale forms were applied to secondary school students studying at secondary schools affiliated to the Ministry of National Education. In the data collection process, in accordance with the permissions received from the Directorate of National Education, secondary school students whose mother tongue is Turkish and whose mother tongue is not Turkish are provided to fill in the forms. Students who were not volunteers and did not answer data collection tools or gave more than one same answer were excluded from the study. 
106 of the secondary school students in the sample are students whose mother tongue is not Turkish and 104 of them are Turkish. 113 of the students in the sample are male and 98 are female. In terms of grade level, there are 57 fifth grade, 45 sixth grade, 45 seventh grade and 63 eighth grade students.

In the research, The Usage Frequency Scale of Listening/Viewing Strategies in Middle School Students developed by Doğan and Erdem (2017) were used as data collection tools. The data obtained in the research process were analyzed with SPSS 18 program.

\section{Result and Discussion}

The data obtained at the end of the data collection process were evaluated in terms of critical listening / viewing, discriminative listening / viewing and comprehensive listening / viewing dimensions. It was determined that there was no significant relationship between frequency of using listening / monitoring strategies and gender. In terms of listening / viewing strategies, it is concluded that students whose mother tongue is Turkish use listening / viewing strategies more frequently than students whose mother tongue is not Turkish. In terms of the entire of scale, it can be stated that 5th grade students use listening / viewing strategies less frequently than 6 th, 7 th and 8 th grades, and 6 th and 7 th grade students use 8 th grade students.

Along with mental and hereditary factors, mother tongue, which is an environmental factor, has an important effect on the development of listening skill. The structure of the spoken language and the language activities exposed in the environment also affect the development of the individual's listening skill. It is known that students who have different mother tongue and learn Turkish as a second language naturally encounter many problems in terms of language Skills (Aslan, 2018; Kan \& Yeşiloğlu, 2017; Pekgenç, 2019; Susar, 2019; Yıldız \& Kızıltaş, 2018). Research results support this situation. Students whose mother tongue is not Turkish use their listening / viewing strategies less frequently than children whose mother tongue is Turkish. Accordingly, it is recommended to support listening / viewing strategies of secondary school students whose mother tongue is not Turkish and to use metacognitive listening strategies with collaborative methods. 